\title{
Sero-epidemiological Investigation of the Major Abortive Bacterial Agents in Ewes of M'Sila Governorate, Algeria
}

\author{
Laatra ZEMMOURI ${ }^{1.4}$, Mohamed BESBACI ${ }^{2}$, Adel MAMMERI ${ }^{1}$ and Mohamed LAFRI ${ }^{2.3}$ \\ ${ }^{1}$ University of M'Sila, Department of Agronomic Sciences, M'Sila, 28000, Algeria \\ ${ }^{2}$ Institute of Veterinary Sciences, University of Blida 1, PB 270, Soumâa, Blida, Algeria \\ ${ }^{3}$ Laboratory of biotechnology related to animal reproduction, Institute of Veterinary Sciences, \\ Blida, Algeria \\ ${ }^{4}$ National High School of Veterinary Medicine, Bab-Ezzouar, Algiers, Algeria \\ * corresponding author: latra.zemmouri@univ-msila.dz \\ Bulletin UASVM Veterinary Medicine 77(2)/2020 \\ Print ISSN 1843-5270; Electronic ISSN 1843-5378 \\ doi:10.15835/buasvmen-vm:2020.0004
}

\begin{abstract}
The aim of this study was to evaluate the seroprevalence, risk factors and zoonotic threats of the major abortive bacterial agents in sheep of M'Sila Governorate. A total of 184 serum samples were collected from ewes among 16 sheep flocks and tested for Coxiella burnetti, Chlamydia abortus, Brucella spp. and Salmonella abortusovis via ELISA. Simultaneously, a questionnaire was used to collect breeding management data. Seropositive results were as follows : Coxiella burnetti (27.9\%), Salmonella abortusovis (15.9\%), Chlamydia abortus (10.9\%) and Brucella spp. (3.8\%).The use of univariate analysis and multivariate logistic regression showed a highly significant correlation between Coxiella burnetti seropositivity and presence of cats in farms (OR $=5.75 ; 95 \% \mathrm{CI}=1.86-19.9 ; \mathrm{p}=0.001)$, while promiscuity with newly introduced animals was associated to Chlamydia abortus seropositivity (OR=3.37; $95 \% \mathrm{CI}=1.01-14.9 ; \mathrm{p}=0.04$ ). Additionally to the economic losses, the dissemination of Coxiella burnetti and Brucella spp. presents uncontrollable zoonotic hazards.
\end{abstract}

Keywords: abortive bacterial agents, seroprevalence, ELISA, risk factors, ewes.

\section{Introduction}

According to the FAO (FAOSTAT, 2019), the recorded ovine population in Algeria stands is 28.393.602 heads. As a main source of meat production, sheep farming is the most practiced compared to other domestic species in Algeria. According to Algerian Ministry of Agriculture and Rural Development (MARD, 2018), sheep represents $78 \%$ of the total livestock in Algeria.

However, abortions are considered as a major scourge in small ruminants' flocks. When installed, they are difficult to eradicate because of the lack of accurate diagnosis tools. They result in very significant economic losses due to abortion and stillbirth occurrences (Rekiki et al., 2005, Borel et al., 2014). The economic loss linked to the loss of 160 animals and $4146 \mathrm{~L}$ of milk due to abortions in Mali, a country neighbor of Algeria, has been estimated at 7,887,880 FCFA $(11,989$ Euros according to the conversion rate of June 22, 2020) (Sidibe et al., 2013). This constitutes a considerable shortfall for farmers, particularly in countries where incomes are quite low. To these losses, we could add the indirect losses relating to research, prophylaxis and vaccination programs for each abortive agent.

Sheep farming in Algeria, is mainly conducted according to extensive and semi intensive systems, 
also breeding and lambing seasons are random and chronogically indefinite (Kardjadj et al., 2015). The observation and notification of abortions which have multiple causes, often lack precision, consequently farmers habitually consider their ewes as infertile especially when these abortions occur at an early stage of gestation.

Algeria is known for its varied climate; Mediterranean in the North and Saharan in the South. This would explain the disparity in abortion rates across the different regions of the country according to Kardjadj et al. (2015) whom reported high prevalence of abortive agents in small ruminants' flocks ranging from 40 to $88.2 \%$. Furthermore, Hamza and Bouyoucef (2013) reported abortion rates up to $90 \%$ in small ruminants' flocks of the North and the East of Algeria.

Infectious agents are the most plausible causes of abortions in sheep as compared to noninfectious agents. Nevertheless, their differential clinical diagnosis is often difficult and laboratory tests are essential to reveal presence of microbial organisms. The main infectious agents of abortions in sheep are ; Brucella melitensis, Chlamydia abortus (C. abortus), Coxiella burnetii (C. burnetii), Toxoplasma gondii (T.gondii), Salmonella abortusovis (S. abortusovis) and Border disease virus (BDV) (Edmondson et al., 2002; Fthenakis et al., 2012; Borel et al., 2014). Moreover, these agents are mostly zoonotic (Acha and Szyfres, 2003 ; Toma et al., 2004 ; Borel et al., 2014).

Among other factors, lack of hygiene and poor management which increase infection rate by abortive agents, the risk of abortions and stillbirths (Dabaja et al., 2019). Thus, identification of the risk factors associated with abortions and infection occurrence with abortive agents can serve in optimizing flocks' reproductive efficiency. The objective of the present study is to evaluate the seroprevalence and risk factors for abortive bacterial agents in ewes of M'Sila Governorate, focusing on the most incriminated; C. burnetti,

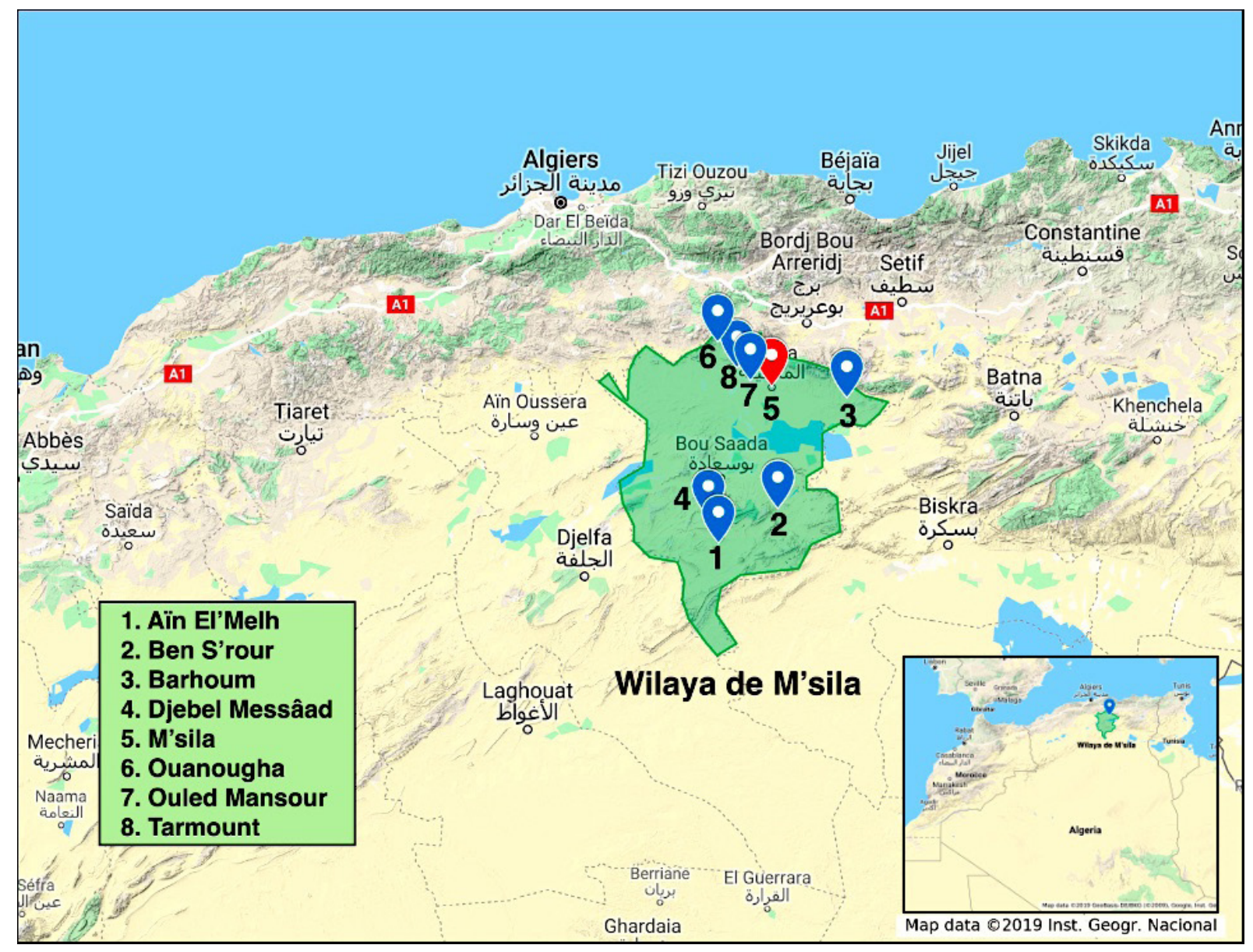

Figure1: Distribution of surveyed municipalities in study area 
C. abortus, Brucella spp. and S. abortusovis, also highlight the eventual zoonotic risks.

\section{Material and methods Description of the study area}

The study was carried out in eight municipalities of M'Sila Governorate (Figure 1). This region occupies the central highlands of Northern Algeria and covers an area of $18175 \mathrm{Km}^{2}$. Its population is estimated at 1.210.952 inhabitants, with an average density of 66 inhabitants $/ \mathrm{km}^{2}$.It is characterized by a continental climate; semi-arid to arid, very reduced maritime influences, a climatic gradient strongly influenced by the topography, since the mountainous zones are culminating at the altitude of $1800 \mathrm{~m}$ while the pre-saharan zones record an altitude of below $300 \mathrm{~m}$. Thus, the climate of M'Sila Governorate is contrasted with a long hot and dry summer season and cold and rainy winter season (ANDI, 2013). It depends on a low and irregular pluviometry not exceeding $250 \mathrm{~mm}$ per year. Regarding animal production, study region is a steppe land with an agro-pastoral vocation (Senoussi et al., 2014). It includes an important sheep herd of over 1.630.000 heads (M'Sila DAS, 2018).

\section{Study design and sampling}

The flocks were selected based on the occurrence of at least one abortion. An epidemiological investigation using an interview via structured questionnaire was conducted focusing on the assessment of risk factors associated with abortion incidence and ELISA test seropositivity. This crosssectional survey took place from January 2016 to June 2018. Questions asked concerned sampled ewes, with dominant items as age, breed, place of born (autochthonic or purchased from livestock markets). While other questions focused on herd management items; flock size, vaccination programs and close promiscuity with other animals.

\section{Blood sample collection and serum separation}

Blood samples were collected from December 2017 to June 2018, using a reasoned sampling according to recommendations of Toma et al. (2001); they were taken from ewes in which parturition or abortion occurred since lesser than one week and 2 weeks, respectively, according to owners' statements. Wholly, 184 sampled ewes reared in 16 flocks counting a total of 4359 sheep and a total of 2562 ewes. Blood had been aseptically collected from the jugular vein into $5 \mathrm{ml}$ sterile vacutainer tubes. After identification, blood samples were transported into low temperature cooler to the university of M'Sila laboratory and then centrifuged at 3000 round per min for $10 \mathrm{~min}$. The sera were stored at $-20^{\circ} \mathrm{C}$ until tested.

\section{Serological tests}

All serological tests were done in the laboratory of serology of Batna Univesity Hospital Center (UHC). Salmonella serology was performed using the recently developed and validated ELISA kit (Diatheva S.r.l, ITALY). The test intended for the detection of IgG anti-Salmonella abortusovis. The assay had sheep-level characteristics of $98 \%$ for specificity and $96 \%$ for sensitivity. Antibodies to C. burnetti, C. abortus and Brucella spp., were detected by a commercial indirect ELISA kit (ID-VET, Grablels-FRANCE) according to the manufacturer's instructions. The presence or absence of antibodies against bacterial abortive agents is determined by calculating the positive to sample ratio for each serum.

\section{Data analysis}

Data was analyzed using $\mathrm{R}$ studio version (version 3.6.2; R Foundation for statistical Computing, Vienna, Austria). Using generalized linear mixed effects models (glmer function of the lme 4 package).We used farm identity as a random variable to account for variation between farms and unequal sample sizes for each farm. We analyzed binary data using logistic regression. Tables representing serology results to the various abortive agents and their percentages were made. A flock is considered positive for an abortive agent if at least one ewe was seropositive for the reliable ELISA test. The disparity of seropositivity between the eight municipalities of study area, were analyzed using Chi-square test. Univariable then multivariable logistic regression analyses were performed for quantifying the associations between seropositivity and specific risk factors. Variables with a pvalue of $\leq 0.2$ in univariable analysis were used in the multivariable logistic regression model. The explanatory variable was assessed with p-value < 0.05 which was considered to be statistically significant. 


\section{Results and discussions}

Herd management and global overview on abortion occurrences in study area

In whole surveyed flocks of M'sila Governorate, sheep farming is the main activity with obvious dominance of Ouled Djellal ovine breed. Many authors agree to recognize several advantages to this breed: maternal skills, reproductive performance, resistance to difficult conditions, walking skills (Dekhili and Benkhlif, 2005, Dekhili, 2014). Hence, it constitutes a socioeconomic pillar for steppic areas' development. Nevertheless, in several regions of Algeria, including M'Sila Governorate, sheep production is even hurdled by reproductive disorders, primordially; abortions, stillbirth and fertility troubles, engendering thus great losses for herders and serious uncontrolled zoonotic risks (Hireche et al., 2014, Feknous et al., 2018 ; Mohamed-Cherif et al., 2019 ; Rouatbi et al., 2019).

Therefore, a good knowledge of abortive agents' epidemiology in M'Sila Governorate, is the key to diminish abortion incidence in its small ruminant flocks. Subsequently, strict measures are required to eradicate abortive enzootic agents via continuous control of specific risk factors associated with abortion occurrence. The dilemma is that diagnostic tests for these abortive agents, excepting for Brucella, are not routinely applied in Algerian veterinary diagnostic laboratories. Moreover, differential clinical diagnosis seems to be eventually confused by non bacterial organisms, as it was remarquably shown by Feknous et al. (2018) the record of apparent seroprevalence of $71.9 \%$ for BDV in M'Sila Governorate.

\section{Seroprevalence of the bacterial abortive agents}

The ELISA serological tests of the four abortive agents indicated that the highest seroprevalence was recorded, respectively, for; C. burnetti, $S$. abortusovis, C. abortus and Brucella spp. (Table 1). Among the 50 positive sera with $C$. burnetti, 33 were strongly positive. All flocks revealed at least one positive test for $C$. burnetti (Figure 2).

Table 1. Seroprevalence results of tested abortive agents in M'Sila Governorate

\begin{tabular}{lccc}
\hline \multicolumn{1}{c}{ Abortive agents } & Seropositive ewes & Seronegative ewes & Seropositivity (\%) \\
\hline C.burnetii & $50 / 184$ & 134 & 27.2 \\
\hline C.abortus & $20 / 184$ & 164 & 10.9 \\
\hline S.abortusovis & $14 / 88$ & 74 & 15.9 \\
\hline Brucella spp. & $7 / 184$ & 177 & 3.80 \\
\hline
\end{tabular}

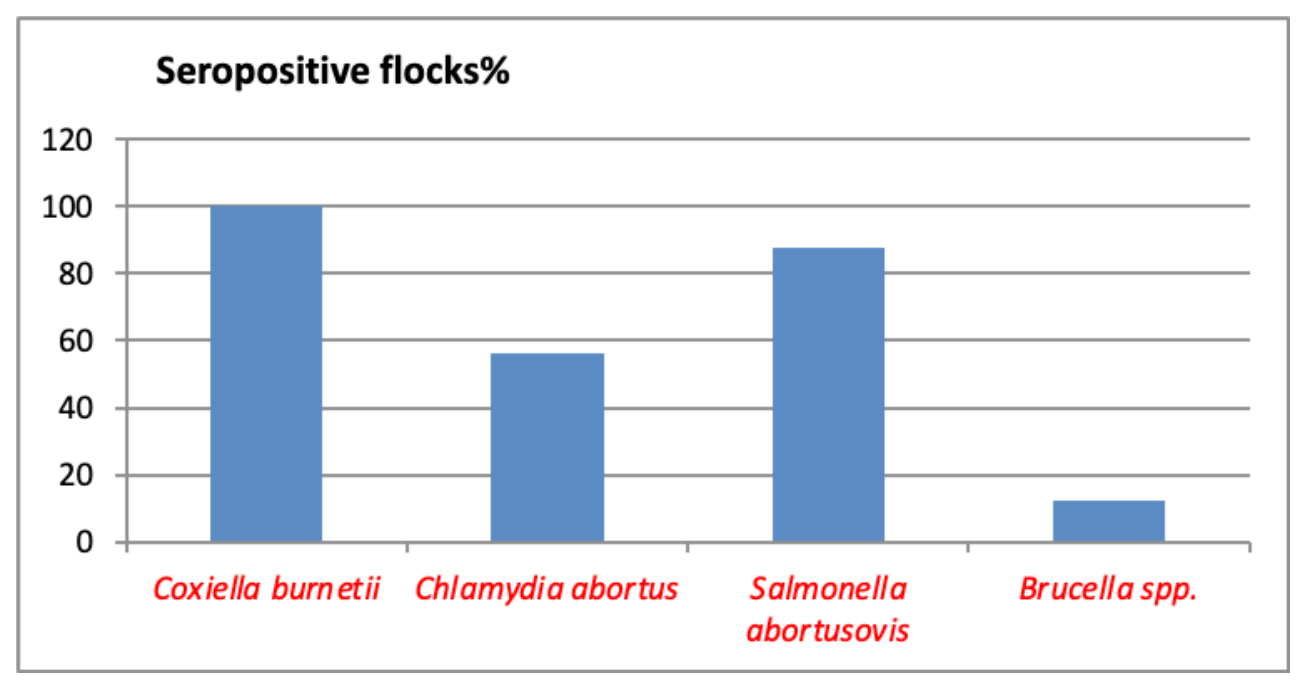

Figure 2: Seroprevalence percentages of abortive agents in whole surveyed flocks 
The highest seroprevalence was recorded for C. burnetti within flock level, for ewes $(27.2 \%)$. Comparatively, this value is higher than that reported by Khaled et al. (2016) for Algeria;14.1\%, and worldwide, higher than those reported by Dabaja et al. (2019) for Lebanon; 24.2\%, Kennerman et al. (2010) for Turkey; 20\%, Asadi et al. (2013) for Iran;19.5\%, Benkirane et al. (2015) for Morocco ; 15.3\%, , Ruiz-Fons et al. (2010) for the South East of Iran ; $11.8 \%$ and Van Den Brom et Vellema (2009) for Netherlands; 2.4\%.However, C. burnetti seroprevalence for this present study is lower than results reported by Bisias et al. (2009) for Greece; 48,8\% and Gebretensay et al. (2019) for Ethiopia; 38\%.

The seroprevalence of $C$. abortus in this present study was $10.9 \%$. Comparatively, it is lower than results reported by Hireche et al. (2014); 24.5\% for the North-Eastern of Algeria and by Merdja et al. (2015) ; 35\% for the North-central of Algeria and worldwide, it is lower than results found by Gebretensay et al.(2019) in Ethiopia; 58.2\%, Benkirane et al. (2015) in Morocco ; 27.2\%, Bisias et al. (2009) in Greece; 14.9\%. Although, our finding as regard to seroprevalence of $C$. abortus, is higher than that reported by ; Abd El-Razik et al. (2011) for Saoudi Arabia; 5,04\%. Unfortunately, there is no current vaccination program against animal coxiellosis, chlamydiosis and salmonellosis in Algeria, this implies infection persistence and more spreading of these abortive agents.

Several authors indicate that $C$. abortus is a major cause of abortions in sheep (Rodolakis and Yousef, 2010 ; Hireche etal., 2014). However, results of the present study showed that $C$. burnetii was most dominant in study area, so that all flocks had at least one seropositive test to $C$. burnetti. In nonpregnant females, infection is typically subclinical with reactivation occurring during pregnancy and excretion of Coxiella in large quantities during parturition in the placental, vaginal and uterine discharges, as well as in milk, urine and feces (Woldehiwet, 2004). This suggests that the disease is already spreading within the flocks, which would explain the high seroprevalence recorded for C.burnetti, respectively, in Barhoum, Ain El'Melh and Djebel Mesâad municipalities (Table 2).

There was significant difference in seropositivity of C.burnetti between municipalities (Chisquare $=14.98, p=0.036$ ) (Table 2 ). The highest seropositivity rate for C.burnetti was recorded in the municipality of Barhoum (Table 2). No disparity in C. abortus seropositivity between municipalities was registered Within this context, the existence of large markets for livestock in Barhoum and Ain El'Melh cities, also, the vast grasslands in Djebel Mesâad limits that could be considered as an im-

Table 2: Animal level seroprevalence of C. burnetti, C. abortus and Brucella spp. in municipalities of M'sila Governorate

\begin{tabular}{lccccccccc}
\hline \multirow{2}{*}{ Municipalities } & $\begin{array}{c}\text { Surveyed } \\
\text { flocks (n) }\end{array}$ & $\begin{array}{c}\text { Total of } \\
\text { flocks (n) }\end{array}$ & $\begin{array}{c}\text { Tested sera } \\
\text { (ewes) }(\mathrm{n})\end{array}$ & $\begin{array}{c}{ }^{*} \text { C.burnetti } \\
\text { seropositivity }\end{array}$ & \multicolumn{2}{c}{$\begin{array}{c}\text { C.abortus } \\
\text { seropositivity }\end{array}$} & $\begin{array}{c}\text { Brucella spp. } \\
\text { seropositivity }\end{array}$ \\
\hline Djebel Messâad & 2 & 517 & 23 & 5 & 21.7 & 3 & 13 & 0 & 0 \\
\hline Ain El'Melh & 3 & 1239 & 35 & 12 & 34.3 & 4 & 11.4 & 6 & 17.1 \\
\hline BenS'rour & 2 & 475 & 25 & 10 & 40 & 3 & 12 & 0 & 0 \\
\hline Tarmount & 2 & 1200 & 24 & 6 & 25 & 0 & 0 & 0 & 0 \\
\hline Barhoum & 1 & 110 & 12 & 7 & 58.3 & 0 & 0 & 0 & 0 \\
\hline Ouanougha & 1 & 54 & 10 & 1 & 10 & 0 & 0 & 0 & 0 \\
\hline Ouled Mansour & 1 & 110 & 15 & 1 & 6.66 & 4 & 26.7 & 0 & 0 \\
\hline M'Sila & 4 & 654 & 40 & 8 & 20 & 6 & 15 & 1 & 2.5 \\
\hline Total & 16 & 4359 & 184 & 50 & - & 20 & - & 7 & - \\
\hline
\end{tabular}

(n) : number * : Chi-square : $14.98 ; p=0.036$ 
portant gathering areas for herds transhuming from neighboring regions, could be in relationship with high seroprevalence recorded for C.burnetti, by shedding bacteria via several pathways and sharing pasture. Commonly, transhumance has already been identified as a risk factor by previous studies in M'Sila Governorate for BDV in sheep by Feknous et al, (2018) and for C.burnetii spreading in Lebanon (Dabaja et al., 2019).

The vaccination of small ruminants against brucellosis with Rev 1 vaccine is practiced in Algeria since more than one decade which could be the cause of the relative low seropositivity for Brucella spp. (3.8\%), compared to the other studied abortive agents. In the present study, there was no significant association between vaccination against brucellosis $(\mathrm{p}=0.46)$ and Brucella spp. seropositivity. Several studies confirmed that vaccination contributes to decrease the chances of brucellosis infections in flocks (Kardjadj and Ben Mahdi, 2014; Kardjadj et al., 2015). In neighbour countries, in Morocco, brucellosis was nearly absent when vaccination campaigns were done, however, the spread of the infection in the whole of the country was noted after stopping of vaccination, so that Benkirane et al. (2015) indicated a seroprevalence of $13.4 \%$ for brucellosis in small ruminants. Similarly, in Tunisia, brucellosis still has a high prevalence in humans and transmitted particularly by ruminants (Khamassi et al., 2018).

In Algeria, seroagglutination test was the habitual technique to identify infections by Salmonella. No abortions due to $S$. abortusovis had been reported since this serotype is not researched in routine laboratory diagnosis. In addition, $S$. abortusovis grows much slower than other Salmonella serotypes, and small colonies could easily be overgrown by other bacteria, especially Escherichia coli which inhibits the growth of S. abortusovis (Borel et al., 2014). The used ELISA test in the present study represents high specificity (98\%) and sensibility (96\%). For $S$. abortusovis seroprevalence, results showed $15.9 \%$ and $87.5 \%$ at ewes' and flocks' levels, respectively. These are higher than results found in Tunisia by (Rekiki et al., 2005); 7.44, and in Switzerland by (Wirz-Dittus et al., 2010); 5\% at flock level. Abortion outbreaks caused by $S$. abortusovis with up to $70 \%$ stillbirth were described in sheep flocks in Switzerland (Belloy et al., 2009). S. abortusovis is specifically adapted to sheep, however, other Salmonella serotypes were found causing abortion in sheep. Indeed, in Spain, Salmonella Indiana was responsible for abortion in dairy ewes (Luque et al., 2009).

Table 3 summarizes the distribution of seropositivity results with regard to more than one abortive agent at the animal and flock levels. Respectively, $56.3 \%$ and $5.43 \%$ of flocks and ewes were seropositive to more than one species of bacterial abortive agent. Mixed infections prevailed in $5.43 \%$ of tested ewes. The major surveyed flocks were infected by two or more abortive agents. This situation is common in many parts of the world (Rekiki et al., 2005; Gebretensay et al., 2019), which need careful investigations. Since they are difficult to interpret, it is essential to confirm strong serological suspicion by using direct diagnosis such as bacteriological isolation and Polymerase Chain Reaction. Concomitant seropositivity to both $C$. burnetti, $C$. abortus and Brucella spp., was found in one ewe's serum belonging to one flock of Ain El'Melh municipality.

Risk factors associated with seropositivity of the abortive agents

Univariable logistic analysis was used for possible associations between risk factors and seropositivity of the studied abortive agents. For multivariable analysis, linear mixed model logistic regression was used for variables with $\mathrm{p} \leq 0.2$ in

Table 3. Distribution of flocks and ewes seropositive to more than one abortive agent

\begin{tabular}{lcc}
\hline Abortive agents coexistence & Seropositive flocks (\%) & Seropositive ewes (\%) \\
\hline C. burnetti + C. abortus & $9 / 16(56.3)$ & $6 / 184(3.26)$ \\
\hline C. burnetti + C. abortus + Brucella spp. & $1 / 16(6.25)$ & $1 / 184(0.54)$ \\
\hline C. burnetti + Brucella spp. & $2 / 16(12.5)$ & $5 / 184(2.72)$ \\
\hline C. abortus + Brucella spp. & $2 / 16(12.5)$ & $1 / 184(0.54)$ \\
\hline C. burnetti + S.abortusovis & $1 / 8(12.5)$ & $2 / 88(2.27)$ \\
\hline
\end{tabular}


univariable logistic regression. The variable (flock) was included in the logistic regression model as a fixed effect. It had been shown that $C$. burnetti seropositivity is significantly higher in farms having not stillbirth problem $(\mathrm{OR}=3.36$; $95 \% \mathrm{CI}$ $=1.18-10.2 ; p=0.01$ ) (Table 4). It is possible that the cause of stillbirth was infection by neither $C$. burnetti nor other abortive agents investigated in this study, but other eventual infectious agents, as reported by several studies revealing very high incidence of BDV (Feknous et al, 2018) and Toxoplasma gondii (Mohamed-Cherif et al., 2019 ; Rouatbi et al. 2019) in Algerian sheep. Indeed, vaccination of pregnant ewes protects them, as well as their lambs, against diseases which are a frequent cause of neonatal mortality like clostridial infections (Fthenakis et al., 2012).

The presence of cats in farm increases 5.7 times infection by C. burnetti $(95 \% \mathrm{CI}=1.86$ 19.9; $\mathrm{p}=0.001$ ) (Table 5). Although, presence of dogs was not associated with seropositivity for the studied abortive agents, most of farmers keep guard dogs near of flocks. May be the dog can prevent the increase of the disease by eating aborted fetuses and preventing the spread of infectious organisms to the environment in which the sheep grazed. However, cats and dogs could play a principal role in the transmission of several abortive and zoonotic agents, especially when they are not treated and vaccinated, as in the case for cats in visited farms of the present study.

Table 4. Risk factors associated with $C$. burnetti and C. abortus seropositivity using univariable logistic regression analysis in flocks of M’Sila Governorate

\begin{tabular}{|c|c|c|c|c|c|c|c|c|c|c|}
\hline \multirow{2}{*}{$\begin{array}{c}\text { Risk } \\
\text { factors }\end{array}$} & \multirow[b]{2}{*}{ Categories } & \multirow{2}{*}{$\begin{array}{c}\text { Tested } \\
\mathbf{n}\end{array}$} & \multicolumn{4}{|c|}{ C. burnetti } & \multicolumn{4}{|c|}{ C. abortus } \\
\hline & & & $\begin{array}{c}\text { Positive } \\
\text { n (\%) }\end{array}$ & OR & $95 \% \mathrm{CI}$ & $P$ & $\begin{array}{c}\text { Positive } \\
\text { n (\%) }\end{array}$ & OR & $95 \%$ CI & $\mathrm{P}$ \\
\hline \multirow{3}{*}{ Flock size } & $<100$ & 20 & $4(8)$ & 1 & & 0.92 & $2(10)$ & 1.51 & $0.15-20.9$ & \multirow{3}{*}{0.91} \\
\hline & $100-300$ & 92 & $27(54)$ & 1.34 & $0.28-6.83$ & & $11(55)$ & 1.24 & $0.23-6.55$ & \\
\hline & $>300$ & 72 & $19(38)$ & 1,2 & $0.22-6.88$ & & $7(35)$ & 1 & & \\
\hline \multirow{3}{*}{$\begin{array}{c}\text { Age } \\
\text { (month) }\end{array}$} & $12-23$ & 40 & $15(30)$ & 1 & & 0.92 & $5(25)$ & 1.51 & $0.15-20.9$ & \multirow{3}{*}{0.91} \\
\hline & $24-35$ & 81 & $15(30)$ & 1.34 & $0.28-6.82$ & & $4(20)$ & 1.24 & $0.23-6.55$ & \\
\hline & $>36$ & 63 & $20(40)$ & 1.19 & $0.22-6.88$ & & $11(55)$ & 1 & & \\
\hline \multirow{2}{*}{$\begin{array}{c}\text { Sheep pox } \\
\text { vaccination }\end{array}$} & Yes & 124 & $27(54)$ & 1 & & 0.13 & $14(70)$ & 1.24 & $0.27-7.46$ & \multirow{2}{*}{0.76} \\
\hline & No & 60 & $23(46)$ & 2.23 & $0.74-6.73$ & & $6(30)$ & 1 & & \\
\hline \multirow{2}{*}{$\begin{array}{l}\text { Presence } \\
\text { of cats }\end{array}$} & No & 89 & $14(28)$ & 1 & & 0.01 & $9(45)$ & 1 & & \multirow{2}{*}{0.83} \\
\hline & Yes & 95 & $36(72)$ & 3.39 & $1.32-9.14$ & & $11(55)$ & 1.15 & $0.25-5.15$ & \\
\hline \multirow{2}{*}{$\begin{array}{l}\text { Stillbirth } \\
\text { occurence }\end{array}$} & Yes & 141 & $31(62)$ & 1 & & 0.04 & $12(60)$ & 1 & & \multirow{2}{*}{0.16} \\
\hline & No & 43 & $19(38)$ & 3.16 & $1.03-10.2$ & & $8(40)$ & 2.58 & $0.63-13.3$ & \\
\hline \multirow{2}{*}{$\begin{array}{l}\text { Nervous } \\
\text { disoders }\end{array}$} & Yes & 83 & $16(32)$ & 1 & & 0.13 & $5(25)$ & 1 & & \multirow{2}{*}{0.12} \\
\hline & No & 101 & $34(68)$ & 2.18 & $0.75-6.38$ & & $15(75)$ & 2,69 & $0.73-12.1$ & \\
\hline \multirow{2}{*}{$\begin{array}{c}\text { Contact } \\
\text { with newly } \\
\text { purchased } \\
\text { animals }\end{array}$} & No & 91 & $22(44)$ & 1 & & 0.51 & $5(25)$ & 1 & & \multirow{2}{*}{0.04} \\
\hline & Yes & 93 & $28(56)$ & 1.41 & $0.47-4.39$ & & $15(75)$ & 3.37 & $1.01-14.9$ & \\
\hline \multirow{3}{*}{$\begin{array}{l}\text { Fertility } \\
\text { disorders }\end{array}$} & ++ & 40 & 7 (14) & 1 & & 0.54 & $1(5)$ & 1 & & \multirow{3}{*}{0.13} \\
\hline & + & 111 & 32 (64) & 1.97 & $0.48-8.58$ & & $16(80)$ & 6.71 & 0.99-132 & \\
\hline & +++ & 33 & $11(22)$ & 2.36 & $0.41-14$ & & $3(15)$ & 3.78 & $0.3-87.3$ & \\
\hline
\end{tabular}

(n) : number 
Table 5: Risk factors associated with $C$. burnetti and C. abortus seropositivity using multivariable mixed effect logistic regression analyses in flocks of M'Sila Governorate

\begin{tabular}{|c|c|c|c|c|c|}
\hline Pathogenic agent & Risk factors & Categories & OR & $95 \%$ CI & $P$ \\
\hline \multirow{8}{*}{ C. burnetti } & \multirow{2}{*}{$\begin{array}{c}\text { Sheep pox } \\
\text { vaccination }\end{array}$} & Yes & 1 & & \\
\hline & & No & 1.42 & $0.61-3.29$ & 0.37 \\
\hline & \multirow{2}{*}{ Presence of cats } & No & 1 & & \\
\hline & & Yes & 5.72 & $1.86-19.9$ & 0.001 \\
\hline & \multirow{2}{*}{$\begin{array}{c}\text { Stillbirth } \\
\text { occurrence }\end{array}$} & Yes & 1 & & \\
\hline & & No & 3.36 & $1.18-10.2$ & 0.01 \\
\hline & \multirow{2}{*}{$\begin{array}{c}\text { Nervous } \\
\text { disorders }\end{array}$} & Yes & 1 & & \\
\hline & & No & 0.34 & $0.08-1.19$ & 0.07 \\
\hline \multirow{9}{*}{ C. abortus } & \multirow{2}{*}{$\begin{array}{c}\text { Contact with } \\
\text { newly purchased } \\
\text { animals }\end{array}$} & No & 1 & & \\
\hline & & Yes & 8.25 & $1.25-167$ & 0.06 \\
\hline & \multirow{2}{*}{$\begin{array}{c}\text { Stillbirth } \\
\text { occurrence }\end{array}$} & Yes & 1 & & \\
\hline & & No & 0.81 & $0.16-3.56$ & 0.76 \\
\hline & \multirow{2}{*}{$\begin{array}{c}\text { Nervous } \\
\text { disorders }\end{array}$} & Yes & 1 & & \\
\hline & & No & 0.57 & $0.02-5.42$ & 0.65 \\
\hline & \multirow{3}{*}{ Fertility disorders } & ++ & 1 & & \\
\hline & & + & 15.8 & $1.95-478$ & 0.03 \\
\hline & & +++ & 5.81 & $0.45-228$ & 0.23 \\
\hline
\end{tabular}

Table 6. Association between risk factors and S.abortusovis seropositivity using univariable and multivariable logistic analyses in flocks of M'Sila Governorate

\begin{tabular}{|c|c|c|c|c|c|c|c|c|c|}
\hline \multirow{2}{*}{ Risk factors } & \multirow{2}{*}{ Categories } & \multirow{2}{*}{$\begin{array}{c}\text { Tested } \\
\mathbf{n}\end{array}$} & \multirow{2}{*}{$\begin{array}{c}\text { Positive } \\
\text { n (\%) }\end{array}$} & \multicolumn{3}{|c|}{ Univariable analysis } & \multicolumn{3}{|c|}{ Multivariable analysis } \\
\hline & & & & OR & $95 \% \mathrm{CI}$ & $\boldsymbol{P}$ & OR & $95 \% \mathrm{CI}$ & $P$ \\
\hline \multirow{2}{*}{ Flock size } & $<300$ & 19 & $1(7.14)$ & 1 & & \multirow{2}{*}{0.11} & 1 & & \multirow{2}{*}{0.33} \\
\hline & $\geq 300$ & 69 & $13(92.8)$ & 4.17 & $0.71-78.2$ & & 1.19 & $0.88-1.64$ & \\
\hline \multirow{2}{*}{$\begin{array}{l}\text { Presence } \\
\text { of poultry }\end{array}$} & yes & 73 & $9(64.3)$ & 1 & & \multirow{2}{*}{0,06} & 1 & & \multirow{2}{*}{0.96} \\
\hline & No & 15 & $5(35.7)$ & 3.55 & $0.93-14.6$ & & 1.01 & $0.68-1.49$ & \\
\hline \multirow{2}{*}{$\begin{array}{l}\text { Dystocia } \\
\text { occurrence }\end{array}$} & Yes & 31 & $3(21.4)$ & 1 & & \multirow{2}{*}{0.2} & 1 & & \multirow{2}{*}{0.1} \\
\hline & No & 57 & $11(78.6)$ & 2.22 & $0.56-10.5$ & & 1.22 & $0.95-1.6$ & \\
\hline \multirow{2}{*}{$\begin{array}{l}\text { Stillbirth } \\
\text { occurrence }\end{array}$} & Yes & 78 & $14(100)$ & 1 & & & & & \multirow{2}{*}{1} \\
\hline & No & 10 & $0(0)$ & NA & & & 0.89 & $0.65-1.22$ & \\
\hline \multirow{2}{*}{$\begin{array}{l}\text { Digestive } \\
\text { disorders }\end{array}$} & Yes & 64 & $8(57.1)$ & 1 & & \multirow{2}{*}{0.17} & 1 & & \multirow{2}{*}{0.51} \\
\hline & No & 24 & $6(42.9)$ & 2.31 & $0.62-8.25$ & & 0.81 & $0.79-1.75$ & \\
\hline \multirow{2}{*}{$\begin{array}{l}\text { Metabolic } \\
\text { diseases }\end{array}$} & + & 37 & $8(57.1)$ & 1 & & \multirow[t]{2}{*}{0.2} & 1 & & \multirow{2}{*}{0.4} \\
\hline & ++ & 51 & $6(42.9)$ & & $0.58-7.46$ & & 0.87 & $0.65-1.15$ & \\
\hline \multirow{2}{*}{$\begin{array}{l}\text { Infectious } \\
\text { diseases }\end{array}$} & ++ & 64 & $8(57.1)$ & 1 & & \multirow{2}{*}{0.17} & 1 & & \\
\hline & + & 24 & $6(42.9)$ & 2.31 & $0.62-8.25$ & & NA & - & \\
\hline \multirow{2}{*}{$\begin{array}{l}\text { Presence } \\
\text { of cats }\end{array}$} & Yes & 73 & $9(64.3)$ & 1 & & \multirow{2}{*}{0.06} & 1 & & \multirow{2}{*}{-} \\
\hline & No & 15 & $5(35.7)$ & 3.55 & $0.93-14.6$ & & NA & - & \\
\hline \multirow{2}{*}{$\begin{array}{l}\text { Nervous } \\
\text { disorders }\end{array}$} & No & 64 & $8(57.1)$ & 1 & & \multirow[t]{2}{*}{0.17} & 1 & & \multirow[b]{2}{*}{-} \\
\hline & Yes & 24 & $6(42.9)$ & 2.31 & $0.62-8.25$ & & NA & - & \\
\hline
\end{tabular}

(n) : number 
The univariable logistic regression revealed that the seropositivity of the four abortive agents was not significantly associated with flock size and ewes age $(\mathrm{p}>0.05)$ (Table 4). However, other studies found association between those risk factors and C.burnetti seropositivity (Gebretensay et al., 2019), and between age and C. abortus seropositivity (Hireche et al., 2014). Contact with newly purchased and introduced animals increases 3.3 times (Table 4) infection by $C$. Abortus (OR=3.37; 95\% CI=1.01-14.9; $\mathrm{p}=0.04$ ).

Using univariable and multivarible regression analyses, all variables were not considered as significant risk factors for $S$. abortusovis seropositivity (Table 6).

\section{Zoonotic risks reliable to abortive agents}

Among socioprofessional categories at high risk of contamination; sheep owners, shepherds households and veterinarians, due to the close permanent promiscuity with anonymous infected animals. Several studies reported zoonotic risks due to abortive agents in Algerian sheep (Hireche $e t$ al., 2014, Feknous et al., 2018 ; Mohamed-Cherif et al., 2019 ; Rouatbi et al., 2019). Regarding zoonotic threat, $C$. burnetti was the subject of several studies worldwide. Animal coxiellosis is considered to be the primary source of human $Q$ fever infections (Angelakis and Raoult, 2010). During an epidemic of $\mathrm{Q}$ fever in humans, which occurred between 2007 and 2009 in the Netherlands, C. burnetii was identified in small ruminants belonging to 30 farms. The proximity of these farms suggested that they were the main cause of 3523 human cases (Roest et al., 2010). In a study carried out in Algeria by Lacheheb and Raoult (2009) between 1995 and 1996 on humans, it had been reported about $18.5 \%$ of seropositive cases for Coxiella, and that among the positive cases; $35 \%$ lived in a rural area versus $7.7 \%$ in an urban area.

Worldwide, brucellosis is considered as a redoubtable bacterial zoonosis with chronic or acute forms (Acha and Szyfres, 2003; Toma et al., 2004). Brucellosis in Algeria is an enzootic disease in small ruminants' flocks and it has a high prevalence in humans, especially in rural areas, due to culinary attitudes and nomadic lifestyle. Similar observations has been reported for Tunisia by Khamassi et al., (2018) and for Morocco by Benkirane et al., (2015). In the same context, companion and guard animals, especially dogs and cats, would play the role of reservoir responsible of shedding Brucella and eventually other zoonotic agents, and thus they should be considered as veritable contaminators for their environment.

\section{Conclusion}

Results of the present study revealed the presence of antibodies against four abortive bacterial agents, with predominance of $C$. burnetti in ewes' sera sampled from M'sila Governorate. Presence of cats in close promiscuity of flocks is considered as risk factor for animal and human coxiellosis. Uncontrolled newly introduced animals, public livestock markets and pasture areas would play a major role for diseases' spreading. The diversity of abortive agents within reproductive sheep may hurdle diagnostic accuracy and increase zoonotic risks. Small ruminants' preventive and therapeutic programs should be systematically and rigorously respected by breeders. It seems necessary to complement research of infectious agents by microbiological isolation in placentas and foetuses of aborted ewes, and after lambing. Control of newly introduced animals in flocks and quarantine should be strictly respected to avoid dissemination and transmission of pathogens.

Acknowledgments. Authors thank Diatheva (S.r.l, ITALY) for financing this study by ELISA kits, also the laboratory of serology staff in Batna Univesity Hospital Center (UHC) for assistance.

\section{References}

1. Abd El-Razik KA, AL-Humiany AA, Ahmed WM, Barakat AMA and ELfadaly HA (2011). Investigations on non Brucella abortifacients in small ruminants in Saudi Arabia with emphasis on zoonotic causes. Global Veterinaria, 6 (1), 25-32.

2. Acha NP, Szyfres B (2003). Zoonoses and communicable diseases common to Man and animals. (Third ed). Vol.1: Bacteriosis and mycosis. Pan American Health Organization (PAHO), Washington, DC,

3. ANDI (National Agency for Investment Development), (2013). Monography of M'Sila Governorate, Algeria.13

4. Angelakis E, Raoult D (2010). Q fever. Vet. Microbiol. 140, 297-309. DOI:10.1016/j.vetmic.2009.07.016

5. Asadi J, Kafi M and Khalili M (2013). Seroprevalence of Q fever in sheep and goat flocks with a history of abortion in Iran between 2011 and 2012.Vet. Ital. 49 (2), 163-168. 
6. Belloy L, Decrausaz L, Boujon P, Hächler H, Waldvogel AS (2009). Diagnosis by culture and PCR of Salmonella abortusovis infection under clinical conditions in aborting sheep in Switzerland. Vet. Microbiol. 138, (3-4), 373-377. DOI: 10.1016/j.vetmic.2009.03.026.

7. Benkirane A, Essamkaoui S, El Idrissi A, Lucchese L, Natale A (2015). A sero-survey of major infectious causes of abortion in small ruminants in Morocco. Vet. Ital. 51, 25-30. Doi: 10.12834/VetIt.389.1814.1.

8. Bisias G, Burriel A, Boutsini S, Kritas S, Leontides L. (2009). A serological investigation of some abortion causes among small ruminant flocks in Greece. The Internet J. Vet. Med.8, (2).

9. Borel N, Caroline F, Frey CF, Gottstein B, Hilbe M, Pospischil A, Franzoso FD, Waldvogel A (2014). Laboratory diagnosis of ruminant abortion in Europe. The Veterinary Journal, 200, 218-229.DOI https://doi.org/10.1016/j. tvjl.2014.03.015.

10. Dabaja MF, Greco G, Villari S, Vesco G, Bayane A, El Bazzal B, Ibrahim E, Gargano V, Sciacca C, Lelli R, Ezzedine M, Mortadah H, Tempesta M, Mortada M (2019). Occurrence and risk factors of Coxiella burnetii in domestic ruminants in Lebanon. Comparative Immunology, Microbiology and Infectious Diseases 64 109-116. DOI https://doi. org/10.1016/j.cimid.2019.03.003.

11. DAS (Directory of Agricultural Services), M'Sila Governorate. (2018). Statistical report on animal production in M'Sila Governorate, Algeria.

12. Dekhili M (2014). Phenotypic and genetic parameters for ewe reproductive performances of Ouled-Djellal breed (Algeria). Arch. zootec. vol.63 no.242 Córdoba jun. 2014 http://dx.doi.org/10.4321/S0004-05922014000200005

13. Dekhili M, Benkhlif R (2005). Bilan portant sur les performances reproductives d'un troupeau de brebis Ouled-Djellal. $12^{\text {es }}$ Rencontres autour des Recherches des Ruminants. INRA, 12: 162.

14. Edmondson MA, Roberts JF, Baird AN, Bychawski S, Pugh DG (2002). Theriogenology of sheep and goats. In: Pugh, D.G., Baird, A.N (Eds.), Sheep and Goat Medicine, (2nd ed), Saunders, Philadelphia, 150-230.

15. FAOSTAT (Food and Agriculture Organization statistics) (2019). Animal production in Algeria.

16. Feknous N, Hanon J, Tignon M et al. (2018). Seroprevalence of border disease virus and other pestiviruses in sheep in Algeria and associated risk factors. BMC Vet Res, 14, 339. https://doi.org/10.1186/s12917-018-1666-y. accessed on 16.3.2020

17. Fthenakis GC, Arsenos G, Brozos C, Fragkou IA, Giadinis ND , Giannenas I , Mavrogianni VS, Papadopoulos E, Valasi I (2012). Health management of ewes during pregnancy. Animal Reproduction Science, 130,198-212.

18. Gebretensay A, Alemayehub G, Rekikc M, Alemub B, Hailed A, Rischkowskyd B, Aklilue F, Wielandb B (2019). Risk factors for reproductive disorders and major infectious causes of abortion in sheep in the highlands of Ethiopia. Small Ruminant Research, 177, 1-9.

19. Hamza K, Bouyoucef A (2013). Assessment of zoonotic risks associated with ruminant abortions for Algerian farmers. Bulletin UASVM, Veterinary Medicine, 70(2).
20. Hireche S, Bouaziz O, Djenna D, Boussena S, Aimeur R, Kabouia R, Bererhi E (2014). Seroprevalence and risk factors associated with Chlamydophila spp. infection in ewes in the northeast of Algeria, Trop. Anim. Health. Prod,46, 467- 473.

21. Kardjadj M, Ben-Mahdi MH (2014). The "effects" of brucella Rev-1 conjunctival vaccination of sheep and goats on human and animal brucellosis in highplateaus area, Algeria. Front. Immunol. Conference. Abstract: The First International Congress of Immunology and Molecular Immunopathology (CIMIP2014). http://dx.doi. org/10.3389/conf.fimmu.2014.04.00002.

22. Kardjadj M, Kouidria B, Metrefa D, Lukac PD, Ben-Mahdi MH (2015). Abortion and various associated risk factors in small ruminants in Algeria. PREVET (article in Press). http://dx.doi.org/10.1016/j.prevetmed.2015.11.015,

23. Kennerman E, Rousset E, Gölcü E, Dufour P (2010). Seroprevalence of $\mathrm{Q}$ fever (coxiellosis) in sheep from the Southern Marmara Region, Turkey.Comparative Immunology, Microbiology and Infectious Diseases, 33, 37-45.

24. Khaled H, Sidi-Boumedine K, Merdja S, Dufour P, Dahmani A, Thierry R, Rousset E, Bouyoucef A (2016). Serological and molecular evidence of $Q$ fever among small ruminant flocks in Algeria.Comparative Immunology, Microbiology and Infectious Diseases, 47, 19-25,

25. Khamassi Khbou M, Htiraa S, Harabech K, Benzarti M (2018). First case-control study of zoonotic brucellosis in Gafsa district, Southwest Tunisia. One Health, 5, 21-26.

26. Lacheheb A, Raoult D (2009). Seroprevalence of Q-fever in Algeria. European Society of Clinical Microbiology and Infectious Diseases, CMI, 15 (Suppl. 2), 167-168.

27. Luque I, Echeita A, Leo'n J, Herrera-Leo'n S, Tarradas C, Gonza' lez-Sanz R, Huerta B, Astorga RJ (2009). Salmonella Indiana as a cause of abortion in ewes: Genetic diversity and resistance patterns. Vet. Microbiol., 134, 396-399.

28. MARD (Ministry of Agriculture and Rural Development), Algeria. Agricole statistics. (2018). http://madrp.gov.dz/ agriculture/statistiques-agricoles/.

29. Merdja SE, Hamza K, Dahmani A, Bouyoucef A (2015). Chlamydial Abortion in Algerian Small Ruminants. Bulletin UASVM Veterinary Medicine , 72 (1). DOI:10.15835/ buasvmcn-vm: 10283.

30. Mohamed-Cherif A, Miroud K, Benfodil K,Ansel S,Khelef D, Kaidi R, Ait-Oudhia K (2019). Cross-Sectional Survey on Toxoplasma gondii Infection in Cattle, Sheep, and Goats in Algeria: Seroprevalence and Risk Factors.Vet. Sci., 6 (3), 63.

31. Rekiki A, Thabti F, Russo P, Sanchis R, Pepin M, Rodolakis A, Hmammi S (2005). Enquête sérologique sur les principales causes d'avortements infectieux chez les petits ruminants en Tunisie. Revue Méd. Vét., 2005, 156, 7, 395-401.

32. Rodolakis A, Yousef Mohamad K (2010). Zoonotic potential of Chlamydophila. Vet. Microbiol., 140 (3-4), pp. 382-91. DOI: 10.1016/j.vetmic.2009.03.014.

33. Roest HI, Tilburg JJ, Van der Hoek W, Vellema P, Van Zijderveld FG, Klaassen $\mathrm{CH}$ (2011). The $Q$ fever epidemic in the Netherlands: history, onset, response and 
reflection. Epidemiol Infect. 139,1-12. DOI : 10.1017/ S0950268810002268.

34. Rouatbi M, Amairia S, Amdouni Y, Boussaadoun MA, Ayadi O, Taha Al-Hosary AA, Rekik M, Ben Abdallah R, Aoun K, Darghouth MA, Wieland B, Gharbi M (2019) Toxoplasma gondii infection and toxoplasmosis in North Africa: a review. Parasite, 26, 6.

35. Ruiz-Fons F, Astobiza L, Barandika JF, Hurtado A, Atxaerandio R, Juste RA, García-Pérez AL (2010) Seroepidemiological study of $\mathrm{Q}$ fever in domestic ruminants in semi-extensive grazing systems. BMC Vet. Res. 6, 3. DOI: 10.1186/1746-6148-6-3.

36. Senoussi A, Hadbaoui I, Huguenin J (2014). The pastoral space in the area of M'sila, Algeria: status and perspectives of rehabilitation. LRRD., 26 (11), Article 206.

37. Sidibe SS, Coulibaly KW, Dakouo M, Tarnagda Z, Sery A, Niang M, Traore K, Nantoume H, Diarra S, Seyni H (2013). Fièvre $Q$ chez les petits ruminants au Mali. Résultats d'une enquête sérologique. Revue d'élevage et de médecine vétérinaire des pays tropicaux, 66 (1) : 11-18.
38. Toma B, André-Fontaine G, Artois M, Augustin C, Bastian S, Bénet J, Cerf O, Haddad N, Lacheretz A, Picavet D, Prave $M$ (2004). Les zoonoses infectieuses. Ecoles nationales vétérinaires françaises, 171p.

39. Toma B, Dufour B, Sanaa M, Bénet JJ, Ellis P, Moutou F, Louza A (2001). Epidémiologie appliquée à la lutte collective contre les maladies animales transmissibles majeures. édition AEEMA, Paris, Maisons-Alfort.551 p.

40. Van den Brom R, Vellema P (2009). Q fever outbreaks in small ruminants and people in the Netherlands. Small Ruminant Research, 86, 74-79.

41. Wirz-Dittus S, Belloy L, Hussy D, Waldvogel AS, Doherr MG (2010). Seroprevalence survey for Salmonella abortus ovis infection in Swiss sheep flocks. PREVET, 97, 126-130. DOI:10.1016/j.prevetmed.2010.08.007.

42. Woldehiwet Z (2004). Q fever (coxiellosis): Epidemiology and pathogenesis. Research in Veterinary Sciences 77, 93-100. 